University at Buffalo School of Law

Digital Commons @ University at Buffalo School of Law

$5-1-2021$

\title{
Reframing Law's Domain: Narrative, Rhetoric, and the Forms of Legal Rules
}

Stephen Paskey

University at Buffalo School of Law

Follow this and additional works at: https://digitalcommons.law.buffalo.edu/journal_articles

Part of the Jurisprudence Commons, Law and Society Commons, and the Speech and Rhetorical Studies Commons

\section{Recommended Citation}

Stephen Paskey, Reframing Law's Domain: Narrative, Rhetoric, and the Forms of Legal Rules, 29 Narrative 178 (2021).

Available at: https://digitalcommons.law.buffalo.edu/journal_articles/1011

Copyright (C) 2021 by The Ohio State University. Also available at Project MUSE.

\section{IN COPYRIGHT}

This Article is brought to you for free and open access by the Faculty Scholarship at Digital Commons @ University at Buffalo School of Law. It has been accepted for inclusion in Journal Articles by an authorized administrator of Digital Commons @ University at Buffalo School of Law. For more information, please contact lawscholar@buffalo.edu. 


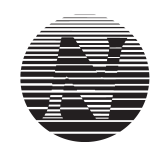

\title{
Reframing Law's Domain: Narrative, Rhetoric, and the Forms of Legal Rules
}

\begin{abstract}
Legal scholars typically understand law as a system of determinate rules grounded in logic. And in the public sphere, textualist judges and others often claim that judges should not "make" law, arguing instead that a judge's role is simply to find the meaning inherent in law's language. This essay offers a different understanding of both the structure of legal rules and the role of judges. Building on Caroline Levine's claim that texts have multiple ordering principles, the essay argues that legal rules simultaneously have three overlapping forms, none of which is dominant: not only the form of conditional, "if-then" logic, but also that of a rhetorical situation (as Lloyd Bitzer defines it) and a stock story, in which the story's elements are reduced to classes of things, acts, and circumstances. As a result, lawyers must tell stories, and legal decisions are a complex act of categorization in which a judge must decide whether the story before the court fits within the category of stories defined by the governing legal rule. This essay further suggests that if storytelling is inherent in law and legal practice, then legal textualism is flawed because it ignores both actual authors and actual audiences. In a very real sense judges do make law, and law's legitimacy in a modern democracy depends on a judge's willingness to consider the divergent voices of those who write the rules and who are bound by or benefit from them.
\end{abstract}

KEYWORDS: legal rhetoric, legal narrative, legal reasoning, textualism

Stephen Paskey is Lecturer in Law at the University at Buffalo School of Law. He teaches legal analysis, writing, oral advocacy, and related skills. His article "Telling Refugee Stories: Credibility, Trauma, and the Adversarial Adjudication of Claims for Asylum" won the Penny Pether Award for Law and Language Scholarship. 
In law, as in literature, "the narratives of the world are numberless" (Barthes 79). While drafting a contract, transactional lawyers engage in speculative fiction, imagining possible plotlines and devising suitable endings. Similarly, litigation is nothing if not a trial by story, in which a jury must weigh competing stories to arrive at something like "truth" - though verisimilitude, as delineated by Todorov, might more accurately describe what they find.

On a deeper level, and within the public sphere, politicians and the public tell stories about law's legitimacy in a modern democracy. As Guyora Binder and Robert Weisberg explain, "some narrative of legitimation is implied in the very ideas of legal authority, legal system, and the state" (261). Efforts to justify the rule of law necessarily take the form of a story, in which the narrator defends our collective consent to be governed by legal institutions. The theme of many such stories is that law should be mimetic, that it should represent the will of society rather than constructing or changing it (Binder 105-7).

The stories we tell about judges are vital to that discourse, and in recent decades a stock villain has emerged: the "activist judge," a judge who supposedly oversteps their role by making law rather than applying it. For many political conservatives, the heroic counterpart is a judge who adheres to legal textualism. Charged with interpreting a statute or constitution, a textualist judge will rely on the text itself, attempting to determine how a "skilled, objectively reasonable user of words" would understand the text in context (Easterbrook 65).

The textualist view is rooted in legal formalism, which holds that "law is an internally consistent and logical body of rules," a system "independent from the variable forms" of the social institutions in which it is situated (Deflem 98). And legal formalism, in turn, is deeply antagonistic to stories. Peter Brooks observes that narrative analysis "would seem to be almost as relevant as economic or social theory to understanding how cases come to the law and are settled by the law" ("Narrative Transactions" 3). And yet law tries "to deny the importance of story, to tame it by legal rule, to interrupt it by cross-questioning, to suppress it through the equation of story with the emotional, the irrational, the dangerous wild card in a discourse committed to reason and syllogism" (Brooks, "Literature" 360).

And so one scholar suggests that legal stories are marked by "failures of integrity and judgment" (Tushnet 251). Another argues that legal stories "distort reality" by imposing a false narrative order on situations "filled with coincidences, randomness, and illogic" (Dershowitz 100, 103). And though Catharine A. MacKinnon identifies herself as a storyteller, she concedes that storytelling may invite judges and juries to suspend their critical faculties. "Lies," she admits, "are the ultimate risk of storytelling as method" (235).

Notwithstanding these attacks, many scholars recognize that narrative and law are "mutually inherent" (Binder and Weisberg 261). Binder and Weisberg suggest that "some of the most basic patterns of thought in law appear to be narratively structured" (264). And in Robert Cover's view, "law and narrative are inseparably related," because every legal prescription demands "to be located in discourse," while 
every legal narrative demands a "prescriptive point" (5). As Linda Edwards explains, narrative "provides the frame through which we see all legal issues and within which all our discourse occurs" (179). But the relationship between law and storytelling may run deeper than we yet understand.

Building on earlier work (Paskey, "The Law"), this essay offers a distinctive account of that relationship, one rooted in the structure of legal rules. I argue that legal rules simultaneously have the form of a rhetorical situation, a stock story, and a conditional "if-then" statement, and that no form dominates the others. After elaborating my thesis, I briefly consider possible implications for public discourse on the role of judges. An accurate and more nuanced understanding of that role calls on us-scholars and the public-to abandon the shopworn notion that judges do not "make" law. Instead, we should recognize that law and legal meaning are "made" in the interplay between legislatures, judges, lawyers, litigants, and the public, through a complex process in which storytelling is essential and inescapable.

\section{II}

On the surface, lawyers tell stories for purely practical reasons. From the standpoint of neurological science, "humans are hardwired to remember information delivered in the form of a story" (Robbins et al. 37). But on a deeper level, lawyers tell stories because storytelling is embedded in the structure of legal rules. In other words, the structure of law dictates that making, interpreting, and enforcing legal rules must necessarily involve acts of storytelling, and that the task of judging is as much about narrative and rhetoric as it is about logic and rules.

Thus James Boyd White was partly right when he insisted that law is "most usefully seen" as a "branch of rhetoric" (684). Law is also a branch of narrative: the two go hand in glove. To explain why this is so, I must say something about rhetoric and stories. But first, I will say something about the nature of legal rules.

The essential points are straightforward. At its core, law consists of rules that delineate duties and discretionary authority (Neumann and Entrikin 8-10). In other words, rules describe actions that someone must or must not take, and actions they may take if they wish. Those constraints are accompanied by socially-imposed consequences for violating the rules and socially-created mechanisms for enacting and enforcing the rules. The consequences are vital—they mark the difference between the Ten Commandments and the Code of Hammurabi, between social norms and legal commands.

The Ten Commandments declare "Thou shalt not steal," but if one does, what then? The text does not dictate a consequence. By contrast, the Code of Hammurabi provides differing penalties for different sorts of theft, some of which are quite severe: "If any one steal [sic] the property of a temple or of the court, he shall be put to death" ("Code" par. 6). The structure is that of a conditional duty: if a person does one thing, the sovereign's agents shall do another.

But what, more precisely, is a legal "rule"? H. L. A. Hart distinguished between two types: the "primary rules of obligation" (those that govern human conduct) and 
the secondary "rules of recognition" (those that govern how primary rules are adopted, interpreted, and enforced) (97-98). The primary rules are "general rules" of social obligation expressed in terms that "refer to classes of people, and to classes of things, acts and circumstances"; by their nature, such rules "operate from a position of generality" and apply to more than one case (Burton 13-14; my emphasis).

It seems obvious, then, that legal rules are a template, in the sense of a preset format or pattern. But a format or pattern for what?

In a seminal article, Lloyd Bitzer defined a "rhetorical situation" - a situation that invites rhetorical discourse (6). As Bitzer framed it, the situation consists of three components. The first, the exigence, is a set of circumstances someone wishes to change. In his words, the exigence is an "imperfection" - "a defect, an obstacle, something waiting to be done, a thing which is other than it should be" (6). The concept is familiar in fairy tales: the porridge is too hot or too cold; the bed too hard or too soft.

The second component, the audience, consists of persons who can change the exigence and might be persuaded to do so. The capacity for intervention is critical, for not every exigence is rhetorical. An earthquake, however powerful, is not a rhetorical exigence because no audience can still the shaking.

Bitzer's final component consists of constraints that limit an audience's desire and ability to change the exigence. For a given situation, the constraints may include "beliefs, attitudes, documents, facts, traditions, images, interests, [and] motives" (8). As in the classical model of rhetoric, some constraints derive from the rhetor-from their "personal character," "logical proofs," and "style" (8).

Taking the components together, a rhetorical situation is one that "strongly invites" rhetoric as a mechanism of change. For Bitzer, a rhetorical situation has intrinsic meaning - a meaning that dictates a "fitting" rhetorical response. Bitzer is not without critics, but the critics (Vatz; Consigny) have focused on his ideas about the relationship between an exigence and the ensuing rhetoric, and not on the validity of his model itself.

The parallels between that model and legal practice are striking. Within a legal system, a primary rule makes an exigence rhetorical and gives it legal meaning. Each rule both defines an exigence and empowers an audience to change it. The rule and the system impose constraints, both on the audience's ability to change the exigence and on the manner of rhetoric employed for that purpose. In a literal sense, a legal rule is a template for a rhetorical situation through which a lawyer engages in rhetoric on a client's behalf.

Rhetorical discourse, then, is integral to law. But what sort of rhetoric will do? In Bitzer's model, the situation itself dictates a "fitting" response. In a legal system, a fitting response is dictated by the customs, habits, and norms of the discourse community in which lawyers and judges perform. Appeals to legal precedent are valid; ad hominem attacks are not. But a fitting response is dictated also by the structure of primary rules, which demand that a lawyer's rhetoric take the shape of a story. A rule is not only a template for a rhetorical situation-it is simultaneously a stock story, the pattern on which a story must be built.

Before I go further, I should clarify what I mean by narrative, story, and stock story. James Phelan's definition of narrative provides a useful starting point. For some 
theorists, a narrative is simply a representation of events in any medium (Chatman). But Phelan defines narrative as an act that includes a speaker, an audience, and a purpose: "Narrative is somebody telling somebody else on some occasion and for some purpose(s) that something happened" (5). A narrative, in other words, is both a noun and a verb: the rhetorical act of telling a story.

For legal narratives, the structuralist distinction between story and discourse is vital. A story consists of events and existents, including characters and setting. The discourse, in turn, consists of the manner and medium in which those elements are represented (Culler 85). To paraphrase Seymour Chatman, the story is "the what" a narrative depicts, the discourse "the how" (19). But legal stories are nonfictional (or purport to be), and a third layer must be added. A nonfictional narrative both refers to and is bounded by the referent, a world that exists outside the text (Cohn 12-14). Without this structuralist framework, it becomes difficult to talk about distinctions between the "brute" facts of a legal case, the differing stories a client or lawyer might construct from those facts, and the varying ways those stories can be presented to different audiences (Paskey, "Telling Refugee Stories" 482-83).

Narrative scholars have debated whether stories necessarily have a plot, but the concept is useful here. For E. M. Forster, a story is simply "a narrative of events arranged in time sequence" (40-42). Thus, in his view, "The king died and then the queen died" is a story, while "The king died, and then the queen died of grief" is a plot. But as Chatman and others argue, our minds infer causation when none is provided, and that causal relationship is the difference between a story and mere description (Tomashevsky 66). In broad terms, a plot involves a narrative arc, a sequence of related rather than random events with a sense of movement. The defining trait is transformation, and "a resolution that marks the change as significant" (Culler 81). Walter Benjamin suggests that every story contains "openly or covertly, something useful" (86) - a moral, a proverb, advice to the reader. There is, in short, a point.

That leaves stock story, and here, Gerald Prince's definitions of stock situation and stock character are useful. A stock character is a recurring character, a conventional type that embodies a quality or role (Prince, Dictionary 92). In 1930s burlesque, for instance, one such type was the "nance" - "a flamboyantly effeminate stock character [who] is all swish, wrist flicks, and double entendres" (Healey). Similarly, Prince defines stock situation as a "standard set of states and events" that can range from the particular ("the birthmark that reveals kinship") to the general (the "rags-to-riches" plot) (Dictionary 92). A stock story, then, is a template in which the elements-events, entities, and plot-are reduced to general types: a pattern for similar stories with common threads but differing details. In folklore, the Cinderella story is a classic example (Abbott 46-48).

With these definitions, what can we make of the relationship between legal rules and stories? Rules are not literally stories, and yet the point obscures a deeper truth. While rules have a logical structure, they are no less grounded in narrative, because every primary rule also has the structure of a stock story. A legal rule-like a stock story-is composed of general types, classes of people, and classes of things, acts, and circumstances. The rule necessarily includes stock characters and stock situations. And rules, like stories, have a "plot," a transformation that is somehow significant. 
To explore the point, consider a New York statute: A person is guilty of burglary if he or she "knowingly enters or remains unlawfully in a building with the intent to commit a crime therein" (NY Penal Law $\$ 140.20$ ). Like other rules, the statute refers to classes of people, things, acts, and circumstances. It embodies the structure of a story: the rule includes stock characters (the alleged burglar and a legal decision-maker) and stock events (the act of entering or remaining, and the judgment). There is also a plot: the elements are logically related by an if-then structure. Equilibrium has been disrupted by the commission of a crime without accountability. A conviction would be the resolution.

The rule links two narratives and two plots: those of the crime and of the criminal. The burglary itself is something that happened to someone or something, and a victim who tells an account of the crime outside the courtroom has constructed a narrative. But that story is one in which the perpetrator goes unpunished, and it functions as a necessary "prequel" to the story of the trial. The criminal law thus attempts to continue the story of the crime and supply a new ending, one in which the criminal is convicted. In effect, the burglary rule, like other legal rules, empowers a court to change the way a nonfictional narrative will end.

If my thesis is right, then much of the criticism leveled at legal storytelling entirely misses the point. I do not argue that stories are never misleading or dangerous: they sometimes are. But in the context of law, storytelling is neither optional nor secondary. One cannot teach law, study law, practice law, investigate a crime, attempt to comply with the law, or decide a legal dispute without telling stories. Wayne Booth observed that "the author cannot choose to avoid rhetoric; he can choose only the kind of rhetoric he will employ" (149). In the same way, lawyers, judges, and legal academics cannot choose to avoid telling stories; they can choose only which stories to tell and how to tell them.

\section{III}

At this point, a skeptical reader might ask: so what? I can only answer that how we think about law matters deeply-to how law is taught and practiced, to be sure, but also to the stories we tell about law, lawyers, and judges in the public sphere.

For over a century, American jurisprudence has been dominated by legal formalism and responses to formalism, especially legal realism, law and economics, and critical legal studies. Today, most scholars reject a strictly formalist view. And yet we still accept that legal reasoning is dominated by logic and determinate rules, by inductive and deductive reasoning. The commonplace defense of law proceeds as if formalism were more or less true.

Anyone who teaches first-year law students has seen this firsthand. Students want to be told what the rules are. They want law to be predictable. They do not want to hear that law is indeterminate, or that values play a larger role than they supposed. And with rare exceptions, they do not want to hear that storytelling is central to law. But that is precisely what legal practice requires. As Prince observes, narrative supplies models for the transformation of reality and "mediates between the law of what 
is and the human desire for what may be" ("On Narratology" 129). This is, of course, precisely what legal rules do-they provide a model by which a lawyer, through the rhetorical act of storytelling, seeks to transform "what is" into the client's desire for "what may be."

\section{IV}

If legal practice demands storytelling, what does that mean for the act of judging? The potential answers are striking.

For any courtroom dispute, a judge or jury will make two critical decisions: what facts have been proven, and how does the law "apply"? The application of law to fact lies at the core of what it means to "think" like a lawyer, and the ways we teach those habits of mind reflect the conventional understanding of law as a logical enterprise. Law school textbooks focus on inductive and deductive reasoning and on arguments from text and precedent, with public policy playing a lesser role. Judges use the same tools and techniques, but there is a different way of thinking about a judge's task.

In an article questioning narratology's distinction between story and discourse, Barbara Herrnstein Smith details the challenges inherent in cataloging versions of the Cinderella story, all of which are similar in some ways and different in others (217-18). Smith argues that the similarities are less about the "deep-plot structure" of the story than the conventions, habits of thought, and experiences of particular readers. In the context of folklore, the task of deciding whether a particular story is a Cinderella story ultimately rests on "some particular, but arbitrary, set of relational criteria" (219), and there is no authority charged with making a definitive assessment.

For all the ways in which law is different from folklore, the task of deciding how the law applies to a given set of facts is remarkably similar to the task of deciding whether a particular story is a Cinderella story, except that in the former case the criteria are less arbitrary and there is a definitive authority-the highest appellate courts. And in both situations, the task involves comparing a specific story to an idealized story type.

Consider again New York's burglary statute. Under that rule, a person is guilty of burglary if they knowingly enter a building unlawfully with intent to commit a crime. Suppose a defendant shimmied into a home's crawl space and stole copper pipes. He admits he is guilty of trespassing and theft, but can he be convicted of burglary, a more serious offense? The answer turns on whether he "entered" the house or crawled under it.

The outcome is neither obvious nor indisputable. In a home without a basement, the crawl space is the space between the ground and first floor, a space that's typically enclosed but not inhabited. Though it's too low to stand in (hence the name), a crawl space often contains much of the home's utility infrastructure, including pipes for water and gas. And while there's rarely direct access from a crawl space to a home's interior, the space is integral to the home's structure. Compared with other spaces that New York courts regard as part of a building (an enclosed porch, or a garage beneath a house), a crawl space is similar in some respects but different in others. 
In my hypothetical, there's no question the defendant entered the crawl space and committed a crime inside it. But the stock story embedded in the burglary rule requires a person to enter a building, and the lawyers will argue about whether the defendant did so. The arguments will be grounded in logic and policy, but they will also attempt to persuade the audience that the defendant's actions either do or do not conform to the rule's stock story.

In ruling on the legal issue-did the defendant enter a "building"? - a judge would deploy the accepted rhetorical moves of legal discourse, most of which are grounded in logic. She would consider definitions of "enter" and "building," review prior court decisions, and use analogical reasoning to compare the crawl space to the facts of prior cases. She might also consider the intent of the legislature and the broader social purpose of laws regarding burglary. I have assigned this exact problem to first-year law students, and I have graded them on how well they do these things.

And yet despite the obvious emphasis on logic and rhetoric, the judge's decision is also an act of literary analysis in which she must compare the story before the court to the stock story embedded in the rule. The burglary rule defines a "genre" of criminal stories, and the judge must determine whether the story told by the prosecutor "fits" within the genre. To do so, the judge must decide if the essential elements-the events and existents - of a burglary story are present. In a sense, the modes of rhetoric commonly employed by judges are conventions by which a judge will make decisions that are not only logical but literary, decisions driven by the substance and meaning of stories.

The trial is thus a complex, overlapping expression of the rule's three forms: rhetoric, narrative, and logic. For the prosecutor, the defendant's purported commission of a crime is both the exigence in a rhetorical situation and a story's disruption of equilibrium, and a conviction is the desired resolution. For defense counsel, the exigence and disruption are the government's purportedly false charges against the defendant, and acquittal the desired resolution. Both lawyers will tell a story consistent with their rhetorical purpose, and both will ground their arguments in logic and underlying facts from the "world" of the case-a world they jointly construct by introducing evidence at trial. Thereafter, a trial judge or appeals court will likewise employ both narrative and logic as rhetorical tools to justify their decision.

What is true for the burglary statute is true for every primary legal rule. In a very real sense, the law is made of stock stories, and each primary rule specifies a genre. In the civil law, there are negligence stories, right of privacy stories, breach of contract stories, and so on. In the criminal law, there are murder stories, kidnapping stories, tax evasion stories, and more. For all the emphasis on logic and reason, the task that lawyers and judges perform when they practice law is also a literary task-one centered on telling stories, analyzing stories, and comparing stories to each other.

None of this is to say that logic is not central to law. It is. Legal rules are not only a template for narrative and rhetoric: they are also a template for a conditional statement. But the logic of law, the "if-then" character of legal rules, is not the logic of physics or mathematics. It is the logic of story, of consequences derived not from "nature" or "god," not from the immutable traits of numbers or things in the world, 
but from the mind of the "author" - the legislature or court-who crafted the stock story embedded in the rule.

In the classic syllogism about Socrates that begins "All men are mortal," the major premise has a truth beyond human thought. No legislature drafted the "rules" of biology and no legislature can repeal them. But in any legal syllogism, the major premise is "true" only because the law makes it so. The law has no truth outside the language of the law, no truth beyond the minds of those who create, interpret, and enforce the law. If anything, then, it is narrative that dominates, for the "if-then" structure of legal rules is a cultural artifact, an imperative derived from the plots of stories rather than from nature or mathematics.

In her recent book Forms, Caroline Levine argues that we should move beyond narrow attempts to define narrative texts as closed systems that simply contain the elements of the story (11). In that spirit, she asks: "What if we understood literary texts not as unified but as inevitably plural in their forms-bringing together multiple ordering principles, both social and literary, in ways that do not and cannot repress their differences?" (40). The same questions might be asked of law and legal rules.

Rules do have the structure of a conditional statement, and legal practice does require rhetorical acts. But to declare that rules are predominantly logical, or that legal practice is rhetoric, is to misstate the nature of law. As Levine suggests, no formal element of a text can ever manage "to contain and control the others" (40). Legal rules embody overlapping ordering principles. They simultaneously have the form of a narrative, a conditional statement, and a rhetorical situation, and the ways in which they operate cannot be fully understood by elevating one of those forms or diminishing another.

\section{V}

No one would seriously claim that judges should decide cases however they wish, or that legal rules mean anything a judge wants them to mean. To espouse that view would be contrary to the very concept of "law," regardless of whether the state is democratic or authoritarian. But scholars and other commentators profoundly disagree on where we should look for suitable constraints on law's meaning.

In an essay defending legal formalism, Frederick Schauer emphasized that the text itself constrains a judge's discretion. To varying degrees that's true, and yet the limits are less definite than most citizens would suppose. Common nouns and verbs are categories, and their meaning is often fluid. A conviction for burglary demands proof that the defendant "entered" a "building," but what, precisely, is a "building"? The word does not conform to the classic model of categories, because a "building" is not a natural kind, and there are no necessary and sufficient conditions that distinguish buildings from things that are not buildings. (In Florida, during a hurricane-related emergency, even a roof is optional.) Instead, whether a thing belongs to the category requires a complex assessment of prototypes (Rosch), family resemblances (Wittgenstein par. 65-71), and the use of both metaphor and metonymy (Lakoff). In short, the boundaries of the category are fuzzy, and there is no definitive "test." The 
interpretive challenge is even greater for categories that encompass our constitutional rights, such as "due process" or "equal protection under law."

Against this backdrop, how should a judge decide what a statute or constitution means? Scholars have vigorously debated this question, and the theories can usefully be understood as appeals to authors, audiences, or the text itself.

For instance, one debate has centered on the distinction between purposivism and textualism. For purposivists, authorial intent is vital, and the text must yield to the author's purpose when the two conflict (Manning 71). Textualists, in turn, argue that the legislative process is too opaque and complex to ascribe a single intent to a multi-member legislative body. As a result, textualism requires that judges treat the clear meaning of the text as conclusive, "even when the text fits poorly with its apparent background purposes" (Manning 73).

Rather than focusing on actual readers, textualist judges assess how a hypothetical reader-a "skilled, objectively-reasonable user of words" (Easterbrook 65)—would understand the text in the context in which it was uttered. In their view, the purposivist focus on legislative intent "disregards the central place of legislative compromise embedded in both the constitutional structure and the corresponding congressional rules of legislative procedure" (Manning 92). In effect, textualists regard the text itself as the only reliable source of meaning, because only the text has been ratified through the often-tumultuous process of enactment. Textualism is also grounded in a particular view of language: the meaning of a rule is inherent in the words of the rule themselves, and the task of a judge is simply to find it.

A second debate has focused on judges as authoritative readers of law and contributors to a joint enterprise. Relying on an "aesthetic hypothesis" (531), Ronald Dworkin argues that judicial interpretation is akin to the composition of a chain novel written by a series of authors, in which each chapter is assigned to a different author in sequence. Just as each author of such a novel is bound by the choices of their predecessors, each judge must regard themselves as "a partner in a complex chain enterprise of which these innumerable decisions, structures, conventions, and practices are the history." A judge's job, then, is "to continue that history into the future" while being constrained by it (543).

In reply, Stanley Fish suggests that Dworkin tried and failed to navigate between two opposing shoals, between the formalist view that "the plain meaning of the law [is] 'just there," waiting to be found, and the legal realist view that judges simply "make up the meaning "wholesale" according to "personal preference or whim" (551). For Fish, interpretation is not an activity in need of external constraint. It is, instead, "a structure of constraints," one that "renders unavailable the independent or uninterpreted text and renders unimaginable the independent and freely interpreting reader" (562). The source of meaning, then, lies solely in the beliefs, assumptions, purposes, and practices of the interpretive community to which a reader belongs.

The theories just discussed are but a sample of the debates. At their core, they differ in how they construct the sources of legal meaning and the place they assign to authors, texts, and audiences. Textualism presumes the meaning of a text is fixed and objective, and ignores both authors and audience; purposivism privileges authors over text and audience; and Fish discounts both authors and text in favor of a com- 
munity of readers. But law is rhetorical-a purposeful act of communication between author and audience. Both authors and audiences are vital, and the text is the ground on which they meet. Any approach to legal interpretation that disregards any of these things or privileges others is fundamentally flawed.

Textualism is especially problematic in that it ignores actual authors and audiences-those who make the rules, and those who are governed by them. In their place, textualists construct a convenient fiction, a hypothetical reader who embodies a set of unspoken assumptions, beliefs, and biases. In effect, textualist judges consistently privilege a single, fictitious interpretive community, one whose beliefs and biases are for the most part their own.

Fish is right to suggest that lawyers and judges form an interpretative community, one bound by a particular way of reading legal texts. But in a modern democratic state-a state grounded in the premise that its citizens consent to be governed-judges and lawyers are not law's only audience, or even its most vital audience. Building on his description of the public sphere, Habermas argues that constitutional review must lend "communicative and participatory rights [.. . ] a privileged position" (265). And so, in the act of constitutional interpretation, judges must simultaneously account for ways in which mass media distorts the public sphere; ensure that "divergent and marginal voices" are heard; and give full and equal representation to all "relevant groups, interest positions, and value orientations" (Habermas 65). In contrast to a textualist approach, Habermas seems to suggest that a judge should embrace all actual readers, should give them all a voice and seek some common thread between them. That approach is consistent with Habermas's theory of discourse-a process in which all citizens affected by a decision have an equal voice and are free to put forward their views without deception or coercion.

\section{VI}

And so we come back to the public sphere, and to public discourse about the role judges play. The public, of course, knows little or nothing of scholarly debate about justice, democracy, and law. Instead, the common understanding of our legal system is grounded in the tropes of high school civics, in ideas about "checks and balances" and the separation of powers. Underlying those ideas is a deep-rooted mistrust of judges, and the common assertion that judges should not "make" law may be intended to soothe the public's apprehension about the power we give them.

If we understand and embrace the view that judges operate in a realm where language and categories are fluid, and where stories and rhetoric are no less essential than logic and reason, how would that change the stories we tell about judges? I have no definitive answer, but several points seem useful.

First, as Binder emphasizes, political representation is an effort to construct the public good rather than simply reflect it. As a result, law does not and cannot mimic the will of society or legal actors. And because law has pragmatic aims, "institutions with arbitrary decision-making procedures and coercive power" are inescapable, and "aesthetic standards such as social decency" are no less germane to evaluating law 
than whether law accurately represents some notion of public will (107). Binder's point is especially important given that modern democracies have not (and likely cannot) achieve Habermas's ideals of full inclusion, free participation, and complete acceptance of both the lawmaking process and the results.

Second, as White suggests, judicial decisions should not be seen as goal-oriented means to an end, but as an effort to determine what law "shall mean in the language of the culture" (697). On a broader level, White argues that law "should take as its central question what kind of community we should be, with what values, motives, and aims. It is a process by which we make ourselves" - both individually and collectively- "by making our language" (698).

In the end, our recognition that storytelling is central to law calls on us to understand and accept that even in a modern democracy, judges necessarily have more power and discretion than we would wish. It further requires us to recognize that our political system is not simply a system of checks and balances, but also one of conscious and inescapable collaboration, in which legislators and judges jointly "make" the law, with input from lawyers, litigants, and the public. Legislators make law by choosing words; judges by giving those words authoritative legal meaning. And that understanding, if truly endorsed, must necessarily alter our expectations for judges, the stories we tell about judges in the public sphere, the traits we seek when we choose judges, and perhaps even the processes by which we choose them and the duration of their tenure.

During a ceremony at the University at Buffalo on August 26, 2019, Justice Ruth Bader Ginsberg was asked to name the essential traits of a judge. She offered three: patience, compassion, and a willingness to listen and learn. Other traits are useful and necessary, but those traits seem fitting in this context. As Paul Gewirtz explains, "literature makes its special claims upon us precisely because it nourishes the kinds of human understanding not achievable through reason alone but often involving intuition and feeling as well" (1050).

We should ask no less from our judges. When all has been said and done, what is it that judges do, if not decide how real-life stories should end? And if the text itself provides an imperfect guide, where else should we seek a fitting interpretation of legal rules if not in a judge's willingness to consider not only the law's authors and varied audiences, not only all "sides" of the story, but also the alternate stories told by divergent and marginalized voices?

\section{Works Cited}

Abbott, H. Porter. The Cambridge Introduction to Narrative. 2nd ed. Cambridge: Cambridge Univ. Press, 2008.

Barthes, Roland. Image - Music_-Text. Translated by Stephen Heath. New York: Hill \& Wang, 1977.

Benjamin, Walter. Illuminations. Edited by Hannah Arendt. Translated by Harry Zohn. New York: Schocken Books, 1992.

Binder, Guyora. "Aesthetic Judgment and Legal Justification.” Studies in Law, Politics, and Society 43 (2008): 79-112. 


\section{Stephen Paskey}

Binder, Guyora, and Robert Weisberg. Literary Criticisms of Law. Princeton: Princeton Univ. Press, 2000.

Bitzer, Lloyd F. “The Rhetorical Situation.” Philosophy \& Rhetoric 1.1 (1968): 1-14.

Booth, Wayne C. The Rhetoric of Fiction. 2nd ed. Chicago: Univ. of Chicago Press, 1983.

Brooks, Peter. "Literature As Law's Other." Yale Journal of Law \& the Humanities 22.2 (2010): 349-67.

_ . "Narrative Transactions_-Does the Law Need A Narratology?" Yale Journal of Law \& the Humanities 18.1 (2006): 1-28.

Burton, Steven J. An Introduction to Law and Legal Reasoning. 2nd ed. Alphen aan den Rijn, Netherlands: Wolters Kluwer, 1995.

Chatman, Seymour. Story and Discourse: Narrative Structure in Fiction and Film. Ithaca, NY: Cornell Univ. Press, 1978.

Cohn, Doritt. The Distinction of Fiction. Baltimore: Johns Hopkins Univ. Press, 1989.

"The Code of Hammurabi." Translated by L. W. King. The Avalon Project, Yale Law School, Lillian Goldman Law Library, n.d. https://avalon.law.yale.edu/ancient/hamframe.asp (accessed 10 January 2020).

Consigny, Scott. "Rhetoric and Its Situations.” Philosophy \& Rhetoric 7.3 (1974): 175-86.

Cover, Robert. "Nomos and Narrative." Harvard Law Review 97.1 (1983): 4-68.

Culler, Jonathan. Literary Theory: A Very Short Introduction. Oxford: Oxford Univ. Press, 1977.

Deflem, Mathieu. Sociology of Law: Visions of A Scholarly Tradition. Cambridge: Cambridge Univ. Press, 2008.

Dershowitz, Alan M. "Life is Not a Dramatic Narrative." In Law's Stories: Narrative and Rhetoric in the Law, edited by Peter Brooks and Paul Gewirtz, 99-105. New Haven: Yale Univ. Press, 1996.

Dworkin, Ronald. “Law as Interpretation.” Texas Law Rev. 60.3 (1982): 527-50.

Easterbrook, Frank H. "The Role of Original Intent in Statutory Construction." Harvard Journal of Law and Public Policy 11 (1988): 59-66.

Edwards, Linda H. "Speaking of Stories and Law." Legal Communication \& Rhetoric: JALWD 13 (2016): 157-79.

Fish, Stanley. "Working on the Chain Gang: Interpretation in Law and Literature." Texas Law Review 60.3 (1982): 551-67.

Forster, E. M. Aspects of the Novel. Boston: Mariner Books, 1963.

Gewirtz, Paul. “Aeschylus’ Law.” Harvard Law Review 101.5 (1988): 1043-55.

Habermas, Jurgen. Between Facts and Norms: Contributions to a Discourse Theory of Law and Democracy. Translated by William Rehg. Cambridge, MA: MIT Press, 1996.

Hart, H. L. A. The Concept of Law. Oxford: Oxford Univ. Press, 1961.

Healy, Patrick. “A Play’s Love Woes Cut Close to Home.” New York Times, 28 March 2013. https:// www.nytimes.com/2013/03/31/theater/in-the-nance-a-reckoning-with-painful-memories.html (accessed 15 December 2020).

Lakoff, George. Women, Fire, and Dangerous Things: What Categories Reveal about the Mind. Chicago: Univ. of Chicago Press, 1990.

Levine, Caroline. Forms: Whole, Rhythm, Hierarchy, Network. Princeton: Princeton Univ. Press, 2017. 
MacKinnon, Catharine A. “Law's Stories as Reality and Politics.” In Law's Stories: Narrative and Rhetoric in the Law, edited by Peter Brooks and Paul Gerwitz, 232-38. New Haven: Yale Univ. Press, 1996.

Manning, John F. "What Divides Textualists from Purposivists?” Columbia Law Review 106.1 (2006): 70-111.

Neumann, Richard K., and J. Lyn Entrikin. Legal Drafting by Design: A Unified Approach. Alphen aan den Rijn, Netherlands: Wolters Kluwer, 2018.

Paskey, Stephen. "The Law is Made of Stories: Erasing the False Dichotomy Between Stories and Legal Rules.” Legal Communication \& Rhetoric: JALWD 11 (2014): 51-82.

—_. "Telling Refugee Stories: Trauma, Credibility, and the Adversarial Adjudication of Claims for Asylum.” Santa Clara Law Review 56.3 (2016): 457-530.

Phelan, James. Somebody Telling Somebody Else: A Rhetorical Poetics of Narrative. Columbus: The Ohio State Univ. Press, 2017.

Phelan, James, and Peter Rabinowitz. "Narrative as Rhetoric." In Narrative Theory: Core Concepts \& Critical Debates, edited by David Herman, 3-8. Columbus: The Ohio State Univ. Press, 2012.

Posner, Richard A. Law and Literature: A Misunderstood Relation. Revised ed. Cambridge, MA: Harvard Univ. Press, 1988.

Prince, Gerald. A Dictionary of Narratology. Revised ed. Lincoln, NE: Bison Books, 2003.

—_. "On Narratology (Past, Present, Future)." In The Narrative Reader, edited by Martin McQuillan, 129. London: Routledge, 2000.

Robbins, Ruth Anne, et al. Your Client's Story: Persuasive Legal Writing. 2nd ed. Alphen aan den Rijn, Netherlands: Wolters Kluwer, 2018.

Rosch, Eleanor H. "Natural Categories.” Cognitive Psychology 4.3 (1973): 328-50.

Schauer, Frederick. "Formalism." The Yale Law Journal 97.4 (1988): 509-48.

Smith, Barbara Herrnstein. "Narrative Versions, Narrative Theories." Critical Inquiry 7.1 (1980): 213-36.

Todorov, Tzvetan. The Poetics of Prose. Translated by Richard Howard. Ithaca: Cornell Univ. Press, 1977.

Tomashevsky, Boris. "Thematics.” In Russian Formalist Criticism: Four Essays, edited by Lee T. Lemon and Marion J. Reis, 61-95. Lincoln: Univ. of Nebraska Press, 1965.

Tushnet, Mark. "The Degradation of Constitutional Discourse.” Georgetown Law Journal 81.2 (1992): 251-311.

Vatz, Richard E. "The Myth of the Rhetorical Situation.” Philosophy \& Rhetoric 6.3 (1973): 154-61.

White, James Boyd. "Law as Rhetoric, Rhetoric as Law: The Arts of Cultural and Communal Life." Univ. of Chicago Law Review 52.3 (1985): 684-702.

Wittgenstein, Ludwig. Philosophical Investigations. 4th ed. Translated by G. E. M. Anscombe, Peter Hacker, and Joachim Schulte. Hoboken: Wiley-Blackwell, 2009. 